\title{
Law Enforcement and Fulfillment of the Right to a Healthy Environment Related to Forest Burning During the Covid-19 Pandemic in Indonesia
}

\author{
Wahyu Nugroho ${ }^{1} \&$ Erwin Syahruddin ${ }^{2}$ \\ ${ }^{1}$ Faculty of Law, Sahid University, Jakarta, Indonesia \\ ${ }^{2}$ IBLAM School of Law, Jakarta, Indonesia \\ Correspondence: Wahyu Nugroho, Faculty of Law, Sahid University, Jakarta. Jl. Prof. Dr. Soepomo, SH. No. 84 \\ Tebet, South Jakarta, Indonesia. Tel: 021-8-3128-13/15-104. E-mail: wahyulaw86@yahoo.com
}

Received: August 13, 2020

doi:10.5539/jpl.v13n4p17
Accepted: September 8, $2020 \quad$ Online Published: October 13, 2020

URL: https://doi.org/10.5539/jpl.v13n4p17

\begin{abstract}
Law enforcement against forest burning during the Covid-19 pandemic was carried out extraordinary. The state is obliged to fulfill the rights of citizens to a good and healthy environment, to overcome forest fires. The country must also restore environmental quality from smoke pollution, as well as the government's commitment to tackling climate change due to forest fires during the Covid-19 pandemic. In this article, the problem is how is law enforcement against forest burning during the Covid-19 pandemic? and how to fulfill community rights to a healthy environment related to forest burning during the Covid-19 pandemic? The method used is a variety of literature and information media during a pandemic related to forest burning, as well as the Law on Environment and Forest Management, using qualitative juridical analysis. In conclusion, first, law enforcement against forest burning during the Covid-19 pandemic is carried out extraordinarily by implementing a system of heavy sanctions, revoking permits, optimizing the recovery costs for Covid-19 response to the results of corporate efforts to guarantee the economy of citizens and donations to the state to address the handling of Covid-19, and to involve indigenous peoples in forest areas with local wisdom that contribute to reducing carbon emissions, so that climate change can be resolved during the Covid-19 pandemic; second, the fulfillment of people's rights to a healthy environment related to forest burning during the Covid-19 pandemic is a state obligation guaranteed by the constitution, maintaining good environmental quality, and Indonesia's commitment to reducing carbon emissions and forest fires due to climate change, as well as law enforcement, oriented towards fulfilling the rights to the environment and health of citizens.
\end{abstract}

Keywords: law enforcement, Covid-19 pandemic, forest burning, environmental rights, healthy

\section{Introduction}

Forest and land fires occur almost every year in parts of Indonesia with various types of motives carried out by individuals and business entities that use forest land for business activities. Since 2015, the Government of Indonesia has intensified the prevention and control of peatland fires, where as much as $35 \%$ of the area burned in 2015 was from the peat ecosystem so that law enforcement against land burning has been strengthened (Myrna A. Savitri, 2020). During the Covid-19 pandemic, there need to be law enforcement measures against forest and land fires in an extraordinary way, because it is related to the impact in the form of smoke pollution due to forest and land fires, while the current condition of the Covid-19 pandemic, health, and environmental aspects are the most important parts. Forest and land fires are among the major catastrophic events that occur in Indonesia. They are a major cause of deforestation and greenhouse gas emissions. Their multiple sources are the most diverse and root in nature and society. The immediate fire effects directly and the long-term landscape ecosystem degradations indirectly cause major and persisting and serious problems of public health and ecosystem service. Smoke haze from the forest and land fires in Sumatra and Kalimantan in 2015 caused significant environmental and economic losses in Indonesia, Singapore, and Malaysia (Purnomo, et al., 2019).

The Indonesian government policy in the new normal period, the activities of companies in the forestry sector, and other natural resources encourage corporations to operate again and the potential for forest fires is getting bigger, even though it remains in the atmosphere of the Covid-19 pandemic. This is the threat of forest and land fires to 
open a business activity during the Covid-19 outbreak (https://kumparan.com/pandangan-jogja/ancamankebakaran-hutan-dan-lahan-di-tengah-pandemi-covid-19-1tfYxD7XY1o, accessed on August 02, 2020). Challenges for the Indonesian Government in enforcing laws against perpetrators of forest and land burning during the Covid-19 pandemic. Besides, there needs to be a guarantee of the fulfillment and protection of the state for the constitutional rights of citizens to a healthy environment. Smoke pollution due to forest and land fires add to the suffering of community members, especially those in forest areas and other natural resource areas that are vulnerable to land burning. The state must also be present in the context of controlling pollution and environmental damage due to a forest and land burning. The downturn in the company's business and economy has prompted corporations to take the initiative to undertake various ways to open business activities, particularly in the field of natural resources.

The lockdown policy in Indonesia since March 2020 has affected corporations in the forestry sector, and some companies implemented lockdowns due to the pandemic, so that forest and land burning activities have decreased significantly. During the Covid-19 pandemic, with the absence of forest burning activities, the Indonesian state, which has natural forest resources, contributed to reducing carbon emissions as a global issue that is also experienced by countries in the world. Law enforcement on forest and land fires during the Covid-19 pandemic must be more firm in taking actions in the form of firm sanctions against perpetrators of forest and land burning. Law enforcement is related to human rights, namely the right of citizens to obtain good health and a healthy environment guaranteed by the Indonesian constitution based on the 1945 Constitution of the Republic of Indonesia. Besides, the importance of environmental law enforcement as a form of monitoring This is extraordinary in the Covid-19 pandemic because it relates to environmental rights and health rights of citizens that must be protected by the state, in addition to efforts to restore the economy of the community due to the Covid-19 pandemic.

Based on Global Wetlands data, Indonesia has the second-largest peatland in the world with an area of 22.5 million hectares. In Indonesia, the province with the largest peatlands in Papua with an area of 6.3 million ha. Followed by Central Kalimantan with 2.7 million ha, Riau 2.2 million ha, West Kalimantan 1.8 million ha, and South Sumatra 1.7 million ha. Besides, there are West Papua 1.3 million ha, East Kalimantan 0.9 million ha, as well as North Kalimantan, North Sumatra, and South Kalimantan which each have 0.6 million ha (Tim Publikasi Katadata, https://katadata.co.id/timpublikasikatadata/infografik/5e9a519433cb1/luas-gambut-indonesia-terbesar-kedua-didunia, accessed on August 02, 2020).

Indonesia, which is currently entering a dry season, is very vulnerable to forest and land fires, especially in peatland areas. Several provinces in Indonesia that frequently experience forest and land fires include Riau, Central Kalimantan, Jambi, South Sumatra, West Kalimantan, and South Kalimantan. For years, people in the province have been breathing unhealthy air due to smog pollution caused by forest and land fires. Riau is a province with the most frequent fire events in Indonesia. The fires are mostly triggered by human activities. The development of plantations by clearing the land using fires was one of the triggers of bigger fires since the peatland was easily burnt. This type of land preparation was found in small-scale land clearance activities by local farmers and in large scale private companies. The development of canals along the peat bog surrounding the plantation also decreased the surface level of peat and dried soil out from the peat, which caused the area to be prone to fire (Erlis Saputra, 2019). Apart from smoke pollution, there is also the threat of Covid-19 which threatens the human respiratory system with a high level of risk. This is where the state's obligation to fulfill the rights of citizens protected by the constitution and statutory regulations on human rights emerges, in particular the right to a good and healthy environment.

Forest and land fires that occur almost every year are still considered commonplace, while administrative, civil law enforcement, and environmental crimes in the context of forest and land fires have not been seriously handled even in normal conditions (before the Covid-19 pandemic). At the same time, the human rights of every citizen in all sectors are still upheld, especially the fulfillment of human rights in the third generation relating to the right to development, information, and a good and healthy environment. According to Suparman Marzuki, the emergence of this third generation of human rights shows that the notion of human rights has shifted from mere concern for the protection of individuals in the face of state absolutism to the creation of social and economic conditions that are calculated to allow individuals to develop their full potential (Suparman Marzuki, 2002).

Currently, human health and safety are a priority, so the state prioritizes health as part of constitutional rights that are protected, guaranteed, and fulfilled by the state. Enforcement of environmental law with a holistic approach is needed that is not only a matter of applying sanctions but how the rights to a healthy environment can be guaranteed, forest ecosystems can be protected and restore the environmental function of forest areas as before. The scope of the discussion and the problem in this paper is how is law enforcement on forest burning during the Covid-19 
pandemic? and how to fulfill the people's constitutional rights to a good and healthy environment related to forest burning during the Covid-19 pandemic?

\section{Method}

In writing this article, the method used is the collection of secondary data in the form of books, journal articles, and information media that are developing and actual in the community during the Covid-19 pandemic on cases of burning forests and land in parts of Indonesia. The author uses normative legal research based on the provisions of the Law on Environmental Protection and Management and the Law on Forestry, as well as other related laws. The author uses qualitative data analysis and legal analysis of forest and land fire events during the Covid-19 pandemic. Various documentation studies and developments in information media for further analysis of legal perspectives on the scope of this discussion.

\section{Result and Discussion}

\subsection{Law Enforcement and Environmental Law Enforcement}

Law enforcement is not an independent activity but has a close reciprocal relationship with the community. Therefore, in discussing law enforcement, discussion of the structure of society that lies behind it should not be neglected. Law enforcement in a society has its tendencies which are caused by the structure of society. This structure is an obstacle, both as the provision of social means that enable law enforcement to be carried out, or it provides obstacles that cause law enforcement to be ineffective or not able to be carried out thoroughly (Satjipto Rahardjo, 2009).

Law enforcement is a very essential and substantial thing in a rule of law, law enforcement is the process of making efforts to uphold or function real legal norms as a code of conduct in traffic or legal relations relating to society and the state (Jimly Asshiddiqie, 2009). Law enforcement is an effort made to implement a rule, both in a narrow formal sense and in a broad material sense, as a code of conduct in every legal action, both by the legal subjects concerned and by law enforcement officials who are legally given the task and authority by law to ensure the functioning of legal norms that apply in social and state life (Hans Kelsen, 2011).

These various conceptions of law enforcement ultimately lead to the objective of the law itself. According to Sudikno Mertokusumo, the main objective of the law is to create an orderly society, to create order and balance. The effort to achieve public order provides a hope that human interests will be well protected. This objective is in its legal function, it is necessary to divide the law to divide rights and obligations between individuals in society, share authority and regulate how to solve legal problems and maintain legal certainty (Sudikno Mertokusumo, 1999).

According to Andi Hamzah, the term law enforcement (environment) has a very broad scope, both preventive (the same as compliance) and repressive (starting with investigative investigations to the application of sanctions both administrative and criminal law. Environmental law occupies a cross point of various fields of a classical law. which can be enforced with one of the instruments, namely administrative, civil, or criminal law instruments, and can even be enforced with these three instruments (Andi Hamzah, 2008).

Based on the results of the study by Elena Ostrovskaya and Jan Leentvaar, it was revealed that the implementation of environmental policies proves to be challenging worldwide, especially in developing countries. The competition between individual and social interests produces confrontation. Thus it is important to analyze the motivations to comply and the behavior of regulated communities in differing developing countries. Monitoring and enforcement significantly impact environmental behavior and environmental quality in developing countries, as well as indicate that there is more than one pathway to high compliance (Elena Ostrovskaya and Jan Leentvaar, 2011).

The difference between 'enforcement' and 'compliance' can be seen in the documents of The United Nations Environment Program (UNEP) \& China ASEAN Environmental Cooperation Center in 2014, stated enforcement: The range of procedures and actions employed by a State, its competent authorities and agencies to ensure that organizations or persons, potentially failing to comply with environmental laws or regulations, can be brought or returned into compliance and / or punished through civil, administrative or criminal action, and compliance: the state of conformity with obligations, imposed by a State, its competent authorities and agencies on the regulated community, whether directly or through conditions and requirements in permits, licenses and authorizations (UNEP, Ministry of Environmental Protection through its China, and ASEAN Environmental Cooperation Center, 2014).

Environmental administration law enforcement as part of an instrument of control and supervision, one of which is the standard criteria for environmental damage to determine the occurrence of environmental damage. In the provisions of Article 21 paragraph (3) letter, c of Law Number 32 of 2009 concerning Environmental Protection 
and Management, one of the standard criteria for ecosystem damage is related to forest and/or land fires.

From the scope of environmental law enforcement mentioned above, it can be given an understanding that environmental law enforcement is an act of government officials and law enforcers to implement various administrative, civil and environmental legal measures regulated in environmental law, not just legal action. after pollution or environmental damage occurs, it is also seen as an instrument of compliance with permits in the context of controlling environmental pollution and/or damage.

In a legal system, the perspective of Lawrence M. Friedman, as quoted by Achmad Ali, consists of the structure, substance, and culture of law (Achmad Ali, 2012). Concerning environmental law enforcement on forest and land fires, first, it is seen from the institutional or structural aspect which has a central function and role as environmental law enforcer that is administrative to legal actions taken by the government against forest burning actors. Environmental agencies/agencies based on Law Number 32 of 2009 concerning Environmental Protection and Management are in the central government and provincial, district/city governments with the authority to make policies, regulations, permits and supervise; then secondly, in terms of statutory regulations or legal substance which are sufficiently strong in the provisions of the law on protection and management of the environment as the main provisions, while the forestry law is a sectoral provision, so that it must be viewed as integral and related to other regulations; Furthermore, the third is related to the legal awareness or legal culture of the community about the importance of preserving forests and not exploiting it on a large scale, including forest management based on the local wisdom of the people of each region.

Enforcement of environmental laws must pay attention to the culture of the community around the forest area who use forest products for their daily life. In the explanation of the provisions of Law No. 18 of 2013 concerning the Prevention and Eradication of Forest Destruction, it has been stated that there are people who live for generations in forest areas whose rights must be protected to use the forest to the extent that they fulfill their daily lives and the explanation in the provisions of Law Number 32 of 2009 concerning Environmental Protection and Management There are indigenous peoples through their local wisdom who burnt forests with a maximum limit of 2 hectares accompanied by traditional rituals in the context of respecting their ancestors.

\subsection{Law Enforcement on Forest Burning During the Covid-19 Pandemic}

The Indonesian government and even countries in the world have had difficulties in enforcing the law on burning forests during the Covid-19 pandemic, so law enforcement must still be carried out, even in the current Covid-19 pandemic conditions. The actions of license holders in the forestry or plantation sector cannot be separated from burning forests and land, and there are prohibited provisions in the environmental protection and management law, forestry law, and plantation law. Enforcement of Indonesian environmental law still places the principle of "ultimum remidium" as the main action with administrative sanctions first, then civil action until environmental crimes are taken at a later date when they do not provide a deterrent effect and are ineffective in the action.

Edwards identified a counter-narrative to the "war on haze" narrative that is in use at all levels of government: the economic growth narrative. Parallel to the target of reducing the number of forest fires and carbon emissions, the Indonesian government has set a target of 7 percent annual growth, which is to be driven in part by the commercial exploitation of Indonesia's forests to produce palm oil. Such levels of economic growth have enabled various actors to undermine the urgency of the securitizing rhetoric, downplay the dangers posed by the haze, and shift policy priorities away from environmental protection towards the commercial-scale expansion of palm oil production (Edwards, Scott Adam, and Felix Heiduk, 2015).

In the provisions of Law Number 32 of 2009 concerning Environmental Protection and Management, forest and / or land fires are one of the standard criteria for environmental damage. The definition of the standard criteria for environmental damage according to this law is a measure of the limits on changes in the physical, chemical, and/or biological characteristics of the environment that can be tolerated by the environment to be able to continue to preserve its functions. The legal responsibility for forest and land fires according to Law Number 41 of 1999 concerning Forestry is the permit holder as stated in the provisions of Article 49 of the Forestry Law that the holder of a right or permit is responsible for the occurrence of forest fires in their working area. In a life during the threat of Covid-19 which is different from previous normal life, extraordinary environmental law enforcement is needed, by applying heavier sanctions, because it relates to human rights in the form of the right to health and the right to a good and healthy environment. for citizens.

From various aspects of environmental law enforcement, administrative legal action by the government is the main door to determine the next legal steps and part of the control function of forest and land fires during the Covid-19 pandemic to determine standard criteria for environmental damage. Besides, the government functions to supervise all actions taken by forestry sector permit holders who are responsible for their territory based on forestry 
provisions in the framework of legal order in the use of natural resources. Administrative law actions and the government's right to sue the license holders in the pandemic era in an extraordinary manner, for now, and in the future, also require technical regulations as operational guidelines in implementing and enforcing in areas prone to forest and land burning, including in the context of protecting rights. citizens' rights to health and a healthy environment.

The Indonesian government is involved in enforcing the law on burning forests and land against many corporations, if it is not taken seriously, then legal action will emerge through the community's right to sue as "class action" or "Citizen Law Suit". One of the interesting cases as a legal step that was successful and deserves appreciation was the granting of the lawsuit of the Citizen Law Suit group of people who are members of the Central Kalimantan Anti-Smoke Movement in which there is a Wahana Lingkungan Hidup organization registered in the Palangka Raya District Court on 16 August 2016 regarding forest and land fire disaster (Wahana Lingkungan Hidup Kalimantan Tengah, http://walhikalteng.org/2019/07/29/konferensi-pers-ma-tolak-kasasi-presiden-atas-gugatancls-asap-rakyat-menuntut-putusan-pengadilan-dijalankan/, accessed on August 6, 2020).

In the lawsuit, the Anti-Smoke Movement held the defendant accountable for negligence in overcoming the haze, and the government should have used the concept of strict liability as regulated in the provisions of Article 88 of Law Number 32 of 2009 concerning Environmental Protection and Management. The defendant itself consists of the President of the Republic of Indonesia and many officials with authority, namely the Minister of Environment and Forestry, the Minister of Agriculture, the Minister of Agrarian Affairs and Spatial Planning / National Land Agency, the Minister of Health, the Governor of Central Kalimantan, and the Regional People's Representative Council of Central Kalimantan. The Supreme Court rejected the appeal of the President and all other officials who were accused in the 2015 forest and land fire case in Central Kalimantan. A decision on Case Number $3555 \mathrm{~K} /$ PDT / 2018 on July 162019 upheld the verdict of the Palangka Raya District Court Number 118 / Pdt.G / LH / 2016 / PN.Plk and the Central Kalimantan High Court Number 36 / PDT / 2017 / PT PLK. The government is obliged to carry out the decision of the Supreme Court and is based on the principle of strict liability provisions for the protection and environmental management in law enforcement (https://www.hukumonline.com/berita/baca/lt5d7fd4bfe9a9c/kasus-karhutla--pemerintah-diingatkan-jalankanputusan-ma/, accessed on August 6, 2020).

This case provides lessons and attention for the government to be consistent and consistent with environmental law enforcement in the forestry sector against forest and land fires by corporations during the Covid- 19 pandemic, where there are citizens' rights that must also be protected and fulfilled, especially the right to a healthy environment. The state is said to have violated the rights of citizens if there is no firm action and is taken seriously by the perpetrators of burning forests and land because it is very threatening to human health, even law enforcement against forest and land fires was carried out in normal life before the Covid-19 pandemic.

Based on Presidential Instruction of the Republic of Indonesia Number 3 of 2020 concerning Handling Forest and Land Fires issued on February 28, 2020, a few days before WHO declared Covid-19 a pandemic, in this Presidential Instruction the President instructed cross-sectoral ministries/agencies, law enforcement officials and Regional governments jointly undertake efforts to control forest and land fires throughout the territory of the Republic of Indonesia, which includes the following activities: a. prevention of forest and land fires; $b$. forest and land fire suppression; and c. post forest and land fire handling. Besides, to make effective law enforcement efforts against criminal acts of forest and land fires as well as payment of compensation according to the level of damage or consequences required for the cost of rehabilitation, restoration of forest and land conditions, or other necessary actions, as well as the imposition of administrative sanctions under the provisions of statutory regulations. This Presidential Instruction should have been followed up with technical regulations by sectoral ministries/agencies, law enforcement officials, and local governments to jointly commit to enforcing the law on forest and land fires during the Covid-19 pandemic, both from the aspect of prevention and enforcement. One of the contents of the Presidential Instruction is to make efforts to impose administrative sanctions and enforce criminal law on business actors who clear and/or cultivate the land by burning.

According to Andri G. Wibisana, forestry/plantation activities are considered very dangerous activities and are indicated by referring to the requirements of Restatement (Second) of Torts $\S 520$, to prove that forest/land fires are a common risk in activities in the forestry sector/plantation, this risk cannot be eliminated by the precautionary action taken by the defendant. Besides, it can be proved that the activities carried out by the defendant were not appropriate to be carried out in the area where the activities were carried out, so that they may be subject to 'strict liability'. The application of strict liability in cases of forest/land fires can easily be justified by referring to various laws and regulations related to forest/land fires. The explanation regarding the statutory regulations for forest/land fires indicates that legal responsibility for forest/land fires rests with the permit holder, regardless of how the permit 
holder carries out his activities. It is sufficient for the Plaintiff to prove that: a). The Plaintiff incurs a loss, b). The fire occurred in the area under the control of the defendant, and c). causality between the plaintiff's losses and the fires that occurred (Andri G. Wibisana, 2016).

The Ministry of Environment and Forestry has three strategies in efforts to prevent forest and land fires, namely: climate analysis and steps through weather modification technology, operational control through field posts, law enforcement, fire-care community, integrated task force, and landscape management through open training. land without burning, and control of peat management. In October-December 2020, forest and land fires are still potential in Nusa Tenggara, while in general the Kalimantan region has a low potential for the potential for forest and land fires, and the prediction of this model is in line with the wet-dry season in 2020 . (https://www.menlhk.go.id/site/single_post/3101/upaya-pencegahan-karhutla-pada-masa-pandemi-covid-19, accessed on August 31, 2020).

In law enforcement for forest and land fires during the Covid-19 pandemic, several alternatives or steps must be taken by the government and law enforcement officials in synergy to take action against permit holders who burned forests and land during the Covid-19 pandemic that could not predict its end. The means of law enforcement against forest and land fires were carried out during the Covid-19 pandemic with a high level of compliance with health protocols. Some alternative steps and possibilities that can be taken during the Covid-19 pandemic are at present and in the future, namely:

First, the mechanism for freezing corporate business licenses in their activities. Forestry activity permits, or leaseto-use permits in forest utilization for mineral and coal mining and plantation business activities, each of which are regulated in separate provisions, may use the means of freezing activity permits until license revocation if they continue to carry out forest and land burning activities during a pandemic, or forest utilization for mining and plantation business activities. Besides, a synergy between central government institutions and local governments, including law enforcement officials, is needed in carrying out surveillance actions against activities in the forest sector which are very dangerous and have an impact on environmental damage. Besides, it requires a common understanding between law enforcement officers and the government regarding Law Number 32 of 2009 concerning Environmental Protection and Management, so that there are no multiple interpretations in implementing these provisions.

Second, the Government makes operational technical arrangements related to the activities of business actors in the forestry sector supported by a digital-based information system and integrated supervision between related institutions in the forestry and environment sector to the regions, so that permit holders in the forestry sector can understand them during the pandemic including land clearing without a burning mechanism. The urgency of integrated monitoring and law enforcement system between institutions during the Covid-19 pandemic has greatly affected the effectiveness of law enforcement, as well as reducing and even eliminating forest and land burning activities during the pandemic.

Third, the government undertakes supervision measures for companies or permit holders who burn forests, to further optimize the cost of recovery to overcome the Covid-19 pandemic, whose uses range from economic security for citizens, company workers, to additional state costs to overcome the complexities of the Covid-19 pandemic. These costs are taken from the results of operations or profits obtained during the pandemic. This system is different from the internalization of environmental costs that already exist in the provisions of Law Number 32 of 2009 concerning Environmental Protection and Management. Internalization of environmental costs is included when starting a business activity until it ends, while recovery costs are the result of profits obtained from business activities in the forestry sector or utilization of forests for other permits such as plantations and mining. The recovery costs from this company are to help the economic recovery of workers who have been laid off as company employees and additional sources of state income to overcome the Covid-19 pandemic.

Fourth, it is necessary to strengthen the central government and regional governments in terms of supervision utilizing business actors who report regularly once a month regarding forest conditions that have the potential to burn especially in peatland areas. During the Covid-19 pandemic, there needs to be a common view of business actors and restructure the government and local government supervision and guidance system. So far, the functions of guidance and supervision in the provisions of Law Number 23 of 2014 concerning Regional Government have not worked, so that the regions interpret their implementation, including the central supervisory function for business actors in the regions because the regional government does not function and there are no firm legal actions against the perpetrators. Effort the central government often takes over regional authority in terms of supervision based on the provisions of Law 32 of 2009 on Environmental Protection and Management, from administrative measures to civil litigation for environmental damage caused by the burning of forests and land, and its impact on 
violations of citizens' rights to health and the environment during a pandemic.

Fifth, the government must work with local communities and indigenous peoples to develop local wisdom in forest utilization. In the provisions of the law on environmental protection and management, it still opens space for indigenous peoples to burn forests and land with a maximum requirement of 2 hectares, but it is also necessary to carry out supervision. The government, in collaboration with communities living in forest areas, applies local wisdom in addition to maintaining sustainable environmental sustainability, also preventing the transmission of Covid-19 using the local wisdom method of each area, as well as clearing land without burning that has local characteristics or regional characteristics. Indonesian indigenous peoples in forest areas greatly contribute to reducing carbon emissions, because their lives depend on nature and a management system based on local wisdom.

Much of the indigenous population of the world already practice sustainable forestry as they have historically relied on forestry resources for their livelihoods. As one briefing paper notes, 'through their age-old sustainable practices, Indigenous Peoples have, in reality, been reducing emissions from deforestation and forest degradation as a result of sustainable forest and resource management practices' (Asia Indigenous Peoples' Pact and the International Work Group for Indigenous Affairs, 2010). The participation of Indigenous People in Reducing Emissions from Deforestation and Forest Degradation (REDD+) governance processes is important to ensure that they are not marginalized at the local level as a result of the international climate change mitigation process. The Indigenous Peoples' Caucus at the Bangkok meeting agreed on three key principles to ensure that Indigenous People are not marginalized by REDD + . There are: first, UNDRIP must constitute a minimum standard of protection for Indigenous People, second, free, prior, informed consent is fundamental to REDD+ governance; and third, traditional knowledge must be recognized (International Forum on Globalization, 2009). To assess whether the domestic legal framework in Indonesia will empower or marginalize Indigenous People in the implementation of REDD+, this section outlines the country's legal history and provides an analysis of customary land ownership as well as discusses Indonesia's land law, forestry law, and laws relating specifically to REDD+ (Glen William Wright, 2011).

A supervisory system in the context of preventive law enforcement and repressive actions against those in charge of businesses or corporations that use forests and land in their business activities requires extraordinary action by strictly implementing health protocols during a pandemic. Fire management, especially on peatlands, also involves the participation of local communities and local indigenous peoples who have long used peatlands with various forms of their traditional knowledge and local wisdom. Indonesian indigenous peoples living in forest areas contribute a lot to reducing carbon emissions, managing forests, and land according to local wisdom, actively taking forms of environmental protection and management of forest areas. Indonesian indigenous peoples who lived in forest areas during the Covid-19 pandemic had local methods derived from their ancestors to protect against large-scale forest and land fires, including protecting their communities from Covid-19 with traditional ritual methods. Their actions indirectly assist the government in dealing with climate change, which is a global issue for countries in the world.

In the Covid-19 pandemic situation, which is exacerbated by burning forests and land, it severely disturbs the rights of the surrounding community members to a good and healthy environment, the right to live in, and economic and social rights, while the license holder's economic activities continue. Of course, there must be a balance between licensing followed by active supervision, and law enforcement outside the judiciary needs to be developed. The weakness of environmental law enforcement or in the context of environmental dispute resolution by litigation through court channels is that it is rigid, formalistic, and the system of decisions taken by the court is in favor of one party or defeating another party. In dispute resolution, various systems and models have grown, not only through the courts, but also outside the court, this is what is called "Alternative Dispute Resolution", and this model is developing rapidly in developed countries such as America, Canada, and European countries to certain matters.

Law enforcement against forest burning during the Covid-19 pandemic is carried out extraordinarily as a function of state control based on its authority over business activities in the forestry sector or utilization of forest areas for other business activities by implementing a system of heavy sanctions, revocation of permits, optimization of recovery costs to overcome the Covid-19 pandemic, from the results of corporate efforts to guarantee the economy of citizens and donations to the state to overcome the handling of the Covid-19 pandemic, as well as involving indigenous peoples in forest areas based on local wisdom which indirectly contributes to reducing carbon emissions, so that climate change as a global issue can be resolved during this Covid-19 pandemic.

\subsection{Fulfillment of Citizens' Rights to a Healthy Environment Related to Forest Burning During the Covid-19}

During the Covid-19 Pandemic, a good environment affected the health of citizens, especially forest areas. 
Environment and health have an important role in human life activities, so that environment and health are interrelated. For the environment to be properly maintained, it is necessary to have regulations in the form of law (Rosmidah Hasibuan, 2018). The rights to the environment of citizens, especially communities around forest or industrial areas by utilizing natural resources will be disturbed, when the state does not fulfill the rights to a healthy environment for its citizens because it is a constitutional right guaranteed in the 1945 constitution. Human health is currently the main thing, so it is also necessary to ensure and guarantee food needs as a basic daily need of citizens because there are restrictions on the socio-economic activities of the community during the current Covid19 pandemic.

The right to a good and healthy environment was originally outlined in Article 28 of the Charter of Human Rights which is part of the Decree of the Indonesian People's Consultative Assembly No. XVII / MPR / 1998 on Human Rights states that: "everyone has the right to a good and healthy environment". Then on August 18, 2000, through the second amendment to the 1945 Constitution formulated the rights referred to in Article $28 \mathrm{H}$ paragraph (1) stated: "Everyone has the right to live in physical and mental prosperity, to live, and to have a good and healthy living environment and the right to obtain health services".

In 1999, Law Number 39 of 1999 concerning Human Rights was issued, in Article 9 paragraph (3) it states: "Everyone has the right to a good and healthy environment. The spirit of the right to a good and healthy environment has been regulated since 1982 regarding the basic provisions of environmental management until the first and second amendments through Law Number 32 of 2009 concerning Environmental Protection and Management. From a global perspective, recognition of the right to a good and healthy environment in Indonesia cannot be separated from international influences related to environmental human rights as stipulated in principle 1 of the Stockholm Declaration which states:

"Man has the fundamental right to freedom, equality and adequate conditions of life, in an environment of a quality that permits a life of dignity and well being any has born a solemn responsibility to protect and improve the environment for present and future generations ...." (Stockholm Declaration of the United Nations Conference on the Human Environment, 1972).

The constitutional basis and recognition of the right to the environment internationally are then adopted into environmental regulations until the second change, and the right of citizens to a good and healthy environment is affirmed as part of the human rights regime. This is stated in Article 65 paragraph (1) of Law Number 32 of 2009 concerning Environmental Protection and Management which states: "Everyone has the right to a good and healthy environment as part of human rights".

Our attention to environmental issues also raises questions about how we are related and related to future generations. We are also invited to think ahead, what is the natural situation or environment in the future? We will realize that our relationship with future generations is irreversible. Hence there is a theory of environmental ethics which in particular gives weight to the interests of future generations in addressing this environmental issue. Whatever we do to nature will affect them. This statement also raises several views on environmental ethics with its specificity in its approach to nature and the environment (Ashabul Kahpi, 2013). The joint reflection carried out by human beings around the world is an important lesson for humans who have so far not had ethics towards the environment and nature, while nature has become the object of exploitation for economic gain or profit alone, without any environmental conservation function, especially in the forestry, plantation and mining sectors.

Reducing forest fires is a long term challenge in Indonesia, driven in part by climate change concerns, but particularly by concerns for public health and pressure from neighboring countries that are frequently affected by the haze generated by fires (Luca Tacconi \& Muhammad Zahrul Muttaqin, 2019). Fires in peatland also result in significant haze pollution which causes a range of negative impacts, including on human health and the economy. The cost to Indonesia of the two largest fire events, which occurred in 1997 and 2015, has been estimated at US\$2.8 billion (Tacconi, 2003) and US $\$ 16.124$ billion respectively, the latter being equivalent to $1.8 \%$ of Indonesia's GDP in 2014 (Tacconi, 2016).

In the conditions of the Covid-19 pandemic, the state also continues to exercise its authority to supervise business activities that utilize forest resources as a framework for environmental law enforcement.

Besides, the state can guarantee the rights of citizens to obtain protection and fulfillment of the right to a good and healthy environment as stated in the constitution and national environmental management policies. Fulfillment of the rights to a healthy environment during a pandemic is important because there is the potential for forest and land burning by corporations. Besides, smoke pollution caused by forest fires is very dangerous to human health. Forest and land fires are seen as a serious problem in environmental law, in addition to harming humans, as well as damaging ecosystems in forest areas. Besides, there is a potential for climate change due to land and forest fires, 
so that there is a direct link between deforestation, climate change, and the risk of forest fires. This is also the commitment of the leaders of the countries in the world to reduce carbon emissions, one of which is caused by forest and land fires for activities in the forestry sector, plantations, and extractive industries that utilize forest areas. The state must ensure and fulfill that the right to a healthy environment for citizens is exercised in times of potential forest and land fires during a pandemic.

Forest and land fires together with the spread of Covid-19 transmission across countries seriously threaten the health of the respiratory system of humans and other living things. The government needs to carry out several strategic agendas in dealing with forest fires, law enforcement, and protection of human rights entering the dry season, especially in forest and peatland areas in parts of Indonesia. The right to the environment, the right to development, and the right to natural resources are the third generation of human rights (Philip Alston, 1982), so it becomes a need for us all to protect and preserve the environment. Compare this to the individual duty component of the third generation right to a healthy environment. In that case, an individual's right to a healthy environment correlates to a state duty to protect the environment, the individual duty of others to protect the environment, and an individual duty of the right-holder herself to protect the environment (Jason Morgan-Foster, 2005). The doctrine about the environmental right talks about these rights as "rights of future generations". We appreciate that they should be seen within the tendency of an assertion of the rights of the fourth generation of rights because right now, the rights of future generations are only some developments trying to crystallize in the form of solidarity rights (Adrian Vasile Cornescu, 2009; Spasimir Domaradzki, Margaryta Khvostova \& David Pupovac, 2019).

During the Covid-19 pandemic, it was at that time that all industrial activities, activities using motorized vehicles stopped so that natural resource exploitation activities could be reduced to protect the earth from increasing carbon emissions, so that pandemic conditions could reduce carbon emissions, which had an impact on the earth's recovery and the environment from motor vehicle fumes, industrial activities, and forest and land burning. However, when business activities have started, the activities of burning forests and land have the potential to be carried out again, so there must be a balance between the rights and obligations of citizens, because economic needs, a healthy environment with health are basic human needs.

Apart from the right to a healthy environment, the right to food is an important part to pay attention to, so that the government must ensure that people or residents do not suffer from hunger during this pandemic by facilitating and providing sufficient foodstuffs. Not only the amount of food supply is sufficient in the market, but the government must ensure that everyone in its territory can easily access this foodstuff, can buy or obtain this food material easily, if the people who are affected by this pandemic, as much as possible the government assists with basic food items for them to get free of charge to overcome the inability to buy food because they no longer have jobs and income during this pandemic (In Karita Sakharina, 2020).

The state must pay attention to the protection and fulfillment of the right to a healthy environment because it is a fundamental issue or fundamental right. The government continues to anticipate and an integrated system of supervision of corporate activities that continue to burn forests to clear land, including activities in the forestry sector, plantations, to mineral and coal mining which also utilize forest areas through borrow-to-use permits, because human rights in the field of environment and adequate housing and health are rights that cannot be reduced. Presidential Instruction of the Republic of Indonesia Number 3 of 2020 concerning Handling Forest and Land Fires should have been followed up with more technical regulations and the formation of an agency or task force consisting of ministries/agencies, law enforcement agencies, and local governments that are directly responsible to the President so that it becomes a need in the conditions of the Covid-19 pandemic to fulfill the human rights of citizens in all areas of life.

Fulfilling the rights of citizens to a healthy environment related to forest burning during the Covid-19 pandemic is the state's obligation that is guaranteed in the constitution, maintaining good environmental quality, from the threat of smoke pollution, and becoming Indonesia's commitment and contribution to reducing carbon emissions and forest fires as a result from climate change. Smoke pollution from forest fires coupled with Covid-19 is a threat to human health, so that protection and fulfillment of the right to a healthy environment is the main thing as something fundamental. Law enforcement that functions to prevent and act against environmental damage due to forest fires in the state's guarantee to protect and fulfill the rights to the environment and the health of citizens.

\section{Conclusion}

Law enforcement against forest burning during the Covid-19 pandemic is carried out extraordinarily as a function of state control based on its authority over business activities in the forestry sector or utilization of forest areas for other business activities by implementing a system of heavy sanctions, revocation of permits, optimization of recovery costs to overcome the Covid-19 pandemic, from the results of corporate efforts to guarantee the economy 
of citizens and donations to the state to overcome the handling of the Covid-19 pandemic, as well as involving indigenous peoples in forest areas based on local wisdom which indirectly contributes to reducing carbon emissions, so that climate change as a global issue can be resolved during this Covid-19 pandemic.

Fulfilling the rights of citizens to a healthy environment related to forest burning during the Covid-19 pandemic is the state's obligation that is guaranteed in the constitution, maintaining good environmental quality, from the threat of smoke pollution, and becoming Indonesia's commitment and contribution to reducing carbon emissions and forest fires as a result from climate change. Law enforcement that functions to prevent and act against environmental damage due to forest fires in the state's guarantee to protect and fulfill the rights to the environment and the health of citizens.

\section{References}

Ali, A. (2012). Menguak Teori Hukum (Legal Theory) dan Teori Peradilan (Judicial Prudence) Termasuk Interpretasi Undang-Undang (Legisprudence). Jakarta: Kencana.

Alston, P. (1982). The Third Generation of Solidarity Rights: Progressive Development or Obfuscation ofInternational Human Rights Law. Netherlands International Law Review, 29(3), 307-322. https://doi.org/10.1017/S0165070X00012882

Asia Indigenous People's Pact and the International Work Group for Indigenous Affairs. (2010). REDD+ and Indigenous Peoples: A Briefing Paper for Policy Makers,"Chiang Mai: Asia Indigenous Peoples' Pact and the International Work Group for Indigenous Affairs.

Asshiddiqie, J. (2009). Penegakan Hukum. Retrieved from http://www.jimly.com/makalah/namafile/56/Penegakan_Hukum.pdf

Cornescu, A. V. (2009). The Generations of Human's Rights, Day práva - 2009. Days of Law: The Conference $\begin{array}{llll}\text { Proceedings } & \text { (1st } & \text { ed.). Brno: Masaryk University. Retrieved from }\end{array}$ https://www.law.muni.cz/sborniky/dny_prava_2009/files/prispevky/tvorba_prava/Cornescu_AdrianVasile.p df

Domaradzki, S., Khvostova, M., \& Pupovac, D. (2019). Karel Vasak's Generations of Rights and the Contemporary Human Rights Discourse. Human Rights Review, 20, 423-443. https://doi.org/10.1007/s12142-019-00565-x

Edwards, A. S., \& Heiduk, F. (2015). Hazy Days: Forest Fires and the Politics of Environmental Security in Indonesia. Journal of Current Southeast Asian Affairs, 34(3), 86. Retrieved from http://nbnresolving.org/urn/resolver.pl?urn:nbn:de:gbv:18-4-9067

Foster, J. M. (2005). Third Generation Rights: What Islamic Law Can Teach the International Human Rights Movement. Yale Human Rights \& Development Law Journal, 8(1), 88. Retrieved from https://digitalcommons.law.yale.edu/yhrdlj/vol8/iss1/2

Hamzah, A. (2008). Penegakan Hukum Lingkungan (Cet.2). Jakarta: Sinar Grafika.

Hasibuan, R. (2018). Pengaturan Hak atas Lingkungan Hidup terhadap Kesehatan. Jurnal Ilmiah Advokasi,"6(2), 99. https://doi.org/10.36987/jiad.v6i2.252

International Forum on Globalisation. (2009). Ensuring Indigenous Peoples' and Forest-Dependent Communities' Rights in REDD (Reducing Emissions from Deforestation and Forest Degradation), Strategy Session, Summary Report and Recommendations. Washington DC: International Forum on Globalization.

Kahpi, A. (2013). Jaminan Konstitusional terhadap Hak atas Lingkungan Hidup di Indonesia. al-Daulah Jurnal Hukum Pidana dan Ketatanegaraan, 2(2), 155. https://doi.org/10.24252/ad.v2i2.1472s

Kelsen, H., penerjemah Muttaqien, R. (2011). Teori Umum Tentang Hukum dan Negara. Bandung: Nusa Media.

Marzuki, S. (2002). Hak Atas Pembangunan Sebagai HakAsasi Manusia. Unisia Jurnal Ilmu-Ilmu Sosial, 25(44), 55. https://doi.org/10.20885/unisia.v0i44.5876

Menteri Lingkungan Hidup dan Kehutanan. (2020, August 9). Upaya Pencegahan Karhutla Pada Masa Pandemi Covid-19. Retrieved from https://www.menlhk.go.id/site/single_post/3101/upaya-pencegahan-karhutlapada-masa-pandemi-Covid-19

Mertokusumo, S. (1999). Mengenal Hukum Suatu Pengantar. Yogyakarta: Liberty.

Ostrovskaya, E., \& Leentvaar, J. (2011, June). Enhancing Compliance with Environmental Laws in Developing Countries: Can Better Enforcement Strategies Help? Paper Presented at the Conference: 9th INECE $\begin{array}{llll}\text { Conference. At British Columbia, Canada. Retrieved from } & \end{array}$ 
https://www.researchgate.net/deref/http\%3A\%2F\%2Fdx.doi.org\%2F10.13140\%2F2.1.4413.0249

Pradana, W. E. (2020, June 23). Ancaman Kebakaran Hutan dan Lahan di Tengah Pandemi Covid-19. Retrieved from https://kumparan.com/pandangan-jogja/ancaman-kebakaran-hutan-dan-lahan-di-tengah-pandemiCovid-19-1tfYxD7XY1o

Purnomo, H., Okarda, B., Shantiko, B., Achdiawan, R., Dermawan, A., Kartodihardjo, H., \& Dewayani, A. A. (2019). Forest and land fires, toxic haze and local politics in Indonesia. International Forestry Review, 21(4), 486-500. https://doi.org/10.1505/146554819827906799

Rahardjo, S. (2009). Penegakan Hukum; Suatu Tinjauan Sosiologis. Cet. I, Yogyakarta: Genta Publishing.

Safitri, M. A. (2020). Sinergi Adaptasi Kearifan Lokal dan Pemberdayaan Hukum dalam Penanggulangan Kebakaran Lahan Gambut di Indonesia. Bina Hukum Lingkungan, 4(2), 198.

Sakharina, I. K. (2020). Hak Atas Pangan di Masa Pandemi Coronavirus Disease Covid-19. Jurnal Legislatif, 3(2), 380. Retrieved from http://journal.unhas.ac.id/index.php/jhl/article/view/10476

Saputra, E. (2019). Beyond Fires and Deforestation: Tackling Land Subsidence in Peatland Areas, a Case Study from Riau, Indonesia. Land, 8(76), 7.

Stockholm Declaration of the United Nations Conference on the Human Environment. (1972). Report of the United Nations Conference on the Human Environment. Retrieved from https://www.un.org/ga/search/view_doc.asp?symbol=A/CONF.48/14/REV.1

Tacconi, L. (2003). Fires in Indonesia: Causes, Costs, and Policy Implications. CIFOR Occasional Paper No. 38, https://www.cifor.org//publications/pdf_files/OccPapers/OP-038.pdf

Tacconi, L. (2016). Preventing fires and haze in Southeast Asia. Nature Climate Change, 6(7), 640-643. Retrieved from https://www.researchgate.net/deref/http\%3A\%2F\%2Fdx.doi.org\%2F10.1038\%2Fnclimate3008

Tacconi, L., \& Muttaqin, M. Z. (2019). Reducing emissions from land-use change in Indonesia: An overview. Forest Policy and Economics, 108. https://doi.org/10.1016/j.forpol.2019.101979

Thea DA., A. (2019, September 17). Kasus Karhutla, Pemerintah Diingatkan Jalankan Putusan MA. hukumonline. Retrieved from https://www.hukumonline.com/berita/baca/lt5d7fd4bfe9a9c/kasus-karhutla--pemerintahdiingatkan-jalankan-putusan-ma/

Tim Publikasi Katadata. (2019, April 29). Luas Gambut Indonesia Terbesar Kedua di Dunia. Katadata.co.id, p.1. Retrieved from https://katadata.co.id/timpublikasikatadata/infografik/5e9a519433cb1/luas-gambutindonesia-terbesar-kedua-di-dunia

UNEP and China ASEAN Environmental Cooperation Centre. (2014). Enforcement of Environmental Law: Good Practices from Africa, Central Asia, ASEAN Countries, and China. The Meetings were convened by UNEP and the People's Republic of China's Ministry of Environmental Protection through its China ASEAN Environmental Cooperation Centre, under the framework of South-South Co-operation, Beijing, China, 1922 May 2014, and a Peer Review Meeting, held in Nairobi, Kenya, 13-14 August, p.1-46. Retrieved from https://wedocs.unep.org/bitstream/handle/20.500.11822/9968/enforcement-environmentallaws.pdf? sequence $=1$ \&isAllowed $=\mathrm{y}$

Walhi Kalteng. (2019, July 29). Konferensi Pers WALHI Kalimantan Tengah: MA Tolak Kasasi Presiden Atas Gugatan CLS Asap. Retrieved from http://walhikalteng.org/2019/07/29/konferensi-pers-ma-tolak-kasasipresiden-atas-gugatan-cls-asap-rakyat-menuntut-putusan-pengadilan-dijalankan/

Wibisana, A. G. (2016). Pertanggungjawaban Perdata untuk Kebakaran Hutan/Lahan: Beberapa Pelajaran dari Menteri Kementerian Lingkungan Hidup dan Kehutanan (KLHK) Vs PT. Bumi Mekar Hijau (BMH). Bina Hukum Lingkungan, 1(1), 53.

Wright, G. (2011). Indigenous People and Customary Land Ownership Under Domestic REDD+ Frameworks: A Case Study of Indonesia. Law, Environment and Development Journal, 7(2). Retrieved from http://www.leadjournal.org/content/11117.pdf

\section{Copyrights}

Copyright for this article is retained by the author(s), with first publication rights granted to the journal.

This is an open-access article distributed under the terms and conditions of the Creative Commons Attribution license (http://creativecommons.org/licenses/by/4.0/). 